\title{
INTERPRETATION OF ANISIAN (MIDDLE TRIASSIC) MARINE INVERTEBRATE FAUNAS FROM THE SOUTHWEST PACIFIC
}

\section{CAMPBELL, Hamish J., DSIR Geology \& Geophysics, PO Box 30368, Lower Hutt, New Zealand}

Early to Middle Triassic marine successions are remarkably lacking in the Southern Hemisphere. It would seem that the best developed and most fossiliferous sequences are preserved in New Zealand. To a lesser extent, successions of Early to Middle Triassic age are known from New Caledonia, New Guinea, the Gympie Basin of Eastern Australia, offshore Western Australia, and western South America (in particular Chile).

Anisian marine faunas were first collected in New Zealand (Etalian local stage) in the 1940s but it was not until 1953 that their age significance was correctly recognised by Marwick. This was later confirmed by Kummel. Since then an unpublished doctoral study has been completed on the paleontology and biostratigraphy of the Anisian succession within the Murihiku terrane of Southland, South Island, New Zealand. A conclusion of this study, based on ammonoid correlations, was that the cosmopolitan halobiid bivalve Daonella appears earlier in New Zealand than it does in North America.

Recent investigations post-date the advent of the tectonostratigraphic terrane concept and suggest that an Anisian fossil record is preserved in at least three terranes in New Zealand (Murihiku, Dun Mountain - Maitai and Torlesse terranes), and two terranes in New Caledonia (probably correlatives of the Murihiku and Torlesse terranes of New Zealand). Analysis of the faunal content of these various terranes suggests that although there are some facies differences (litho and bio), there is little obvious basis for recognition of distinct paleobiogeographic provenance.

A corollary to this research on Anisian faunas is the recognition that the New Zealand ammonoid faunas previously considered to be Early Triassic (Malakovian local stage; Murihiku terrane) by Kummel are almost certainly Anisian. However, this does not imply that there isn't an Early Triassic sedimentary record. Significant thicknesses of apparently unfossiliferous sequence are present in each of the relevant terranes. Two isolated Early Triassic ammonoid faunas are now known from elsewhere in New Zealand but from tectonically complex settings in Brook Street (?) and Dun Mountain - Maitai terranes. 